\title{
"The impact of the deferred tax adjustment on the Economic Value Added (EVA) measure"
}

\begin{tabular}{ll}
$\begin{array}{l}\text { AUTHORS } \\
\text { ARTICLE INFO }\end{array}$ & $\begin{array}{l}\text { Melissa Naicker } \\
\text { Economic Value Added (EVA) measure. Investment Management and Financial } \\
\text { Innovations, 14(3), 227-242. doi:10.21511/imfi.14(3-1).2017.07 }\end{array}$ \\
\hline DOI & http://dx.doi.org/10.21511/imfi.14(3-1).2017.07 \\
\hline RELEASED ON & Monday, 13 November 2017 \\
\hline RECEIVED ON & Saturday, 29 April 2017 \\
\hline ACCEPTED ON & Thursday, 21 September 2017 \\
\hline LICENSE & $\begin{array}{l}(c c) \text { EY } \\
\text { This work is licensed under a Creative Commons Attribution } 4.0 \text { International }\end{array}$ \\
\hline JOURNAL & License \\
\hline ISSN PRINT & "Investment Management and Financial Innovations" \\
\hline ISSN ONLINE & $1810-4967$ \\
\hline PUBLISHER & $1812-9358$ \\
\hline FOUNDER & LLC “Consulting Publishing Company “Business Perspectives" \\
\hline
\end{tabular}

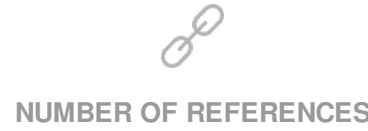

34

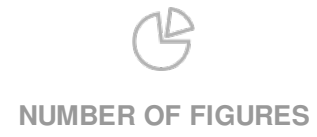

4

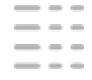

NUMBER OF TABLES

6

(C) The author(s) 2022. This publication is an open access article. 


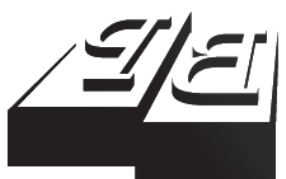

BUSINESS PERSPECTIVES

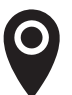

LLC "CPC "Business Perspectives" Hryhorii Skovoroda lane, 10, Sumy, 40022, Ukraine

www.businessperspectives.org

Received on: 29 $9^{\text {th }}$ of April, 2017

Accepted on: $21^{\text {st }}$ of September, 2017

(C) Melissa Naicker, 2017

Melissa Naicker, Master's Degree in Management Accounting, Lecturer, Department of Management Accounting, Faculty of Accounting and Informatics, Durban University of Technology, South Africa.

\section{THE IMPACT OF THE DEFERRED TAX ADJUSTMENT ON THE ECONOMIC VALUE ADDED (EVA) MEASURE}

\begin{abstract}
Economic Value Added (EVA) is a value-based accounting measure used by companies to measure the amount of value created for shareholders. EVA requires the conversion of accounting values to economic values. This conversion process is known as the EVA adjustment. If accounting values are not converted to economic values, the value of the EVA can be distorted. Previous studies have shown that companies are experiencing difficulties in implementing EVA adjustments. To reduce these difficulties, companies have decided to limit their EVA adjustments to ten or even fewer. The research problem is that if the appropriate adjustments are not made, an inaccurate EVA measure will be calculated.

The aim of the research is to measure whether deferred taxes impact EVA. The study is conducted within a quantitative research paradigm. Secondary data analysis was carried out on JSE-listed food producers over a seven-year period, from 2004 to 2010. The unadjusted EVA was compared to the adjusted EVA measure to determine the before and after effects of deferred taxes on EVA. The findings of the study revealed that deferred taxes either understated or overstated the value of the EVA during the period 2004-2010. In addition, the results from the regression analysis revealed an overall significance for all deferred tax predictors. The results from the study showed that deferred tax had a significant impact on the value of EVA. Therefore, the study recommends that companies implement the deferred tax adjustment on EVA.
\end{abstract}

Keywords

JEL Classification

\section{INTRODUCTION}

During recent years, there has been an increasing emphasis on the concept of value creation. Many corporations around the world are focusing on making decisions that create value for the company and for the shareholder. Shareholders are considered as one of the most important stakeholders in a company, as the investment in shares is a primary source of capital.

It is, therefore, essential for managers to act in the best interests of shareholders by making decisions that will benefit the shareholder, and, hence, create shareholder value (Collier, 2012). Consequently, the primary goal of management is to increase shareholder wealth by aligning the interests of management with that of shareholders (Lovata \& Costigan, 2002). Sharma and Kumar (2010) also agree that companies are focusing more on maximizing shareholder value.

In order to maximize shareholder value, a tool is required to measure shareholder value. Many companies are using $E V A$ as a tool to measure shareholder value. The EVA measure is the registered trademark of a New York-based consulting company, Stern Stewart and distributed under the terms of Creative Commons Attribution 4.0 International license, which permits unrestricted re-use, distribution, and reproduction in any medium provided the original work is properly cited. 
Company. During the late 1980s, Bennett Stewart and Joel Stern pioneered the EVA measure as one of the value-based accounting measures (Stewart, 1991).

EVA is a tool used to measure the amount of value the company has created and, consequently, measures the amount of value created for shareholders. The $E V A$ measure indicates if the company has created value or destroyed value (Latha, 2009). Ray (2001) points out that EVA has been used increasingly and successfully in the corporate world by corporate giants such as Coca-Cola, AT\&T, Briggs Stratton, DuPont, Eli Lilly and Quaker Oats. Stern Stewart and company created the following EVA formula:

$$
E V A=N O P A T-(T C E \times W A C C \%), E V A=N O P A T-C O C .
$$

The above formula can be reduced by multiplying TCE by WACC\% to yield COC, where NOPAT - Net operating profit after taxes; TCE - Total capital employed; WACC\% - Weighted average cost of capital percentage; $C O C$ - Cost of capital.

With reference to the EVA formula, NOPAT represents the profits generated by the company from using invested capital (TCE). TCE represents the amount of capital invested in the company, which constitutes shareholder capital and borrowed capital. The COC represents the cost of using the capital (TCE) invested in the company. The aim is for companies to generate a return (NOPAT) that would exceed the cost of using capital $(C O C)$. A positive EVA ( NOPAT $>C O C)$ indicates value creation, whilst a negative EVA ( NOPAT <COC) represents value destruction (Young, 1997).

The computation of the EVA measure requires the extraction of accounting information from company annual financial statements (AFS). AFS are prepared according to accounting standards and, therefore, reflect accounting values. Burksaitiene (2009) makes an important point by stating that accounting values are distorted due to the application of Generally Accepted Accounting Practices (GAAP).

Furthermore, accounting values need to be adjusted to reflect an economic value for the purposes of calculating EVA. For example, the 'profit for the period', as reflected on the statement of comprehensive income, and 'capital', as reflected on the statement of financial position, are accounting values. These accounting values need to be converted to economic values. The 'profit for the period' is converted to an economic value called net operating profit after taxes (NOPAT). Likewise, 'capital' is converted to an economic value called total capital employed (TCE). The conversion of accounting values to economic values is referred to as an adjustment (Burksaitiene, 2009).

Converting accounting values to economic values is important for the purposes of calculating EVA. Economic values must be reflected in the EVA measure, hence, the term 'Economic Value Added'. According to Stewart (1991), EVA must also be adjusted for other accounting transactions that take place during the year. The accounting transactions include research and development, operating leases, depreciation and deferred taxes. The EVA must be adjusted for accounting transactions, because these transactions are accounting values that affect the values of NOPAT and TCE. The NOPAT and TCE are components of $E V A$. Therefore, adjustments to NOPAT and TCE are synonymous to adjusting the EVA measure.

However, Sharma and Kumar (2010) believe that companies are experiencing difficulties in understanding and implementing adjustments. In addition, Young (1997) states that companies have decided to keep their adjustments to ten or fewer in order to prevent the EVA system from becoming complicated. Furthermore, Young (1997) indicates that some companies prefer not to make any adjustments so that the system is easier to administer and comprehend. The research problem is that the accuracy of the EVA measure is affected for companies that are not prepared to implement the appropriate accounting adjustments. This paper seeks to make a contribution towards improving the accuracy of the EVA measure. This will be achieved by investigating the impact of the deferred tax adjustment on the EVA measure. 


\section{CONCEPTUAL FRAMEWORK}

According to Stewart (2013), there are several accounting adjustments that can be made to EVA. Accounting adjustments constitute the removal of accounting transactions. There are many types of accounting transactions, namely, operating lease transaction, research and development (R\&D) transaction and the deferred tax transaction. These accounting transactions are removed because of their distorting impact on EVA. For example, the operating lease transaction distorts EVA. To remove the distortion, an operating lease adjustment is made to EVA. The operating lease adjustment is one type of an accounting adjustment. In the context of this study, the deferred tax transaction distorts EVA. To remove the distorting impact of deferred taxes on $E V A$, a deferred tax adjustment is implemented for $E V A$. The deferred tax adjustment is another example of an accounting adjustment.

The implementation of an accounting adjustment for EVA will require adjusting the components of EVA, namely, NOPAT and TCE. To elaborate, the implementation of accounting adjustments for EVA entails the removal of accounting transactions from NOPAT and TCE. The accounting transactions are removed from the unadjusted NOPAT, to arrive at the adjusted NOPAT. Similarly, the accounting transactions are removed from the unadjusted TCE to arrive at the adjusted TCE. The implementation of accounting adjustments ensures that accurate values for NOPAT and TCE (adjusted NOPAT and adjusted TCE) are produced. Consequently, an accurate EVA value (adjusted $E V A$ ) is produced (Larrabee \& Voss, 2012).

\section{LITERATURE REVIEW}

\subsection{The unadjusted NOPAT and the adjusted NOPAT}

The following studies analyzed the overall impact of accounting transactions on NOPAT.

Studies by Nichols, Gray, and Street (2005), Bhattacharya, Black, Christensen and Larson (2003), Black and Christensen (2009), Aubert, (2009) and Eames and Sepe (2005) investigated the impact of accounting adjustments on NOPAT. These studies examined the before and after effects of accounting transactions on NOPAT. The accounting transactions included amortization, restructuring charges, $\mathrm{R} \& \mathrm{D}$, impairment losses, merger and acquisitions, gains and losses on asset dispositions and stockbased compensation costs. The findings by Nichols et al. (2005), Bhattacharya et al. (2003), Black and Christensen (2009), Aubert (2009) and Eames and Sepe (2005) yielded similar results. The findings revealed that accounting transactions distorted NOPAT. The implementation of accounting adjustments showed a lower unadjusted NOPAT and a higher adjusted NOPAT. These studies concluded that accounting transactions understated NOPAT. In contrast, the study by Marques (2010) provided a mixed set of results. The empirical results revealed an understated NOPAT for $52 \%$ of companies and an overstated NOPAT for $48 \%$ of companies.

\subsection{The unadjusted TCE and the adjusted TCE}

The following studies examined the impact of individual accounting adjustments on TCE.

Studies by Damodaran (2009) and Bryan, Lilien, and Martin (2010) examined the impact of the operating lease transaction on TCE. These studies yielded similar results, as the unadjusted TCE was lower than the adjusted TCE. The findings revealed that the operating lease transaction understated TCE.

A study by Callimaci and Landry (2004) and Cazavan-Jeny and Jeanjean (2006) examined the impact of the R\&D transaction on TCE. Callimaci and Landry (2004) found that the R\&D transaction understated TCE, as the unadjusted TCE was lower than the adjusted TCE. In contrast, the empirical findings by Cazavan-Jeny and Jeanjean (2006) found that the R\&D transaction understated and overstated TCE during the sample period.

Another study by Damodaran (2007) provided a comprehensive set of results, as the study individually examined the impact of four different types of accounting transactions on TCE. The results of the study showed that the depreciation transaction understated TCE, the R\&D transaction understated and overstated TCE, the operating lease transaction understated TCE and the goodwill transaction understated TCE. 
Previous empirical evidence shows that accounting transactions (such as operating leases, depreciation, merger costs) distort the value of NOPAT and TCE. The above studies show that the implementation of accounting adjustments removes the distorting effect of accounting transactions and, in turn, will produce accurate values for NOPAT and TCE.

\subsection{The unadjusted NOPAT, adjusted NOPAT and deferred tax expenses}

Noor, Mastuki, and Aziz (2007) and Herbohn, Tutticci, and Khor (2010) explain that there has been an increasing trend amongst companies in using deferred tax expenses to manage NOPAT. The empirical findings from the above studies showed that a decrease in deferred tax expenses resulted in a higher unadjusted NOPAT and a lower adjusted NOPAT. These studies concluded that a decrease in the provision for deferred tax expenses resulted in an overstated NOPAT.

In addition, the following studies investigated whether deferred taxes were useful in detecting the management of NOPAT. Phillips, Pincus and Rego (2002) and Chang, Herbohn, and Tutticci (2009) suggest that an increase in deferred tax expenses resulted in a lower unadjusted NOPAT and a higher adjusted NOPAT. The above studies concluded that an increase in the provision for deferred tax expenses resulted in an understated NOPAT.

\subsection{The unadjusted TCE, adjusted TCE and deferred tax assets/liabilities}

Previous studies by Gee and Mano (2006) and Gallermore (2012) investigated the relationship between deferred tax assets and TCE in the banking sector. The above studies showed that banks were using deferred tax assets to maintain an adequate level of TCE. Gee and Mano (2006) and Gallermore (2012) yielded similar empirical results as both studies found that deferred tax assets resulted in a higher unadjusted TCE and a lower adjusted TCE. This finding revealed that deferred tax assets overstated TCE. Furthermore, Gee and Mano (2006) and Gallermore (2012) suggest that the reporting of a deferred tax liability would result in a lower unadjusted TCE and a higher adjusted TCE. These studies suggest that the deferred tax liabilities would understate TCE.

The above studies provided evidence that deferred tax expenses distorted NOPAT and that deferred tax assets/liabilities distorted TCE.

\subsection{Empirical evidence on accounting adjustments and EVA}

Previous studies provided empirical evidence on the components of EVA (NOPAT and TCE) and on the different types of accounting adjustments (the deferred tax adjustment being one of the accounting adjustments). However, very few studies have been conducted on EVA and accounting adjustments (Latha, 2009). A database search showed that there was only one study that examined the role of adjustments on EVA. A study by Anderson, Bey, and Weaver (2005) investigated the impact of accounting adjustments on the EVA measure. The study was found to be the most relevant piece of literature in relation to this research study.

The study conducted by Anderson et al. (2005) investigated the impact of five types of accounting adjustments on EVA. The five accounting adjustments included the R\&D adjustment, operating lease adjustment, advertising adjustment, last-in-first-out (LIFO) adjustment and the bad debts adjustment. The study compared the unadjusted EVA (value of the $E V A$ before accounting adjustments) to the adjusted $E V A$ (value of the EVA after accounting adjustments). The results of the study showed that R\&D and LIFO were the two out of the five adjustments that accounted for a major change in the value of the EVA. Furthermore, the regression statistics revealed a lack of statistical significance in relation to the accounting adjustments and EVA.

The reason for the lack of statistical significance was due to the selection of the number and type of adjustments. The number and types of adjustments resulted in a lack of commonality. The lack of commonality resulted in the lack of com- 
parability. As a result, the overall results could not determine a material effect of accounting adjustments on EVA (Anderson et al., 2005).

In order to prevent the difficulties experienced by Anderson et al., the researcher has chosen only one adjustment. Deferred tax has been chosen, as it is an adjustment that occurs every year for each company and is also a common adjustment between companies. This is evident as a review of the sample companies' AFS showed that each company recognized deferred tax. The deferred tax values were reflected on each company's statement of comprehensive income and on the statement of financial position. In addition, deferred taxes were reflected on each company's AFS for each year starting from 2004 to 2010 (sample period). As a result, the deferred tax adjustment facilitates comparability during each sample year for a single company and between each company.

According to Latha (2009), there is much room for studies to be conducted on the importance and significance of accounting adjustments on EVA within a different sector and under different GAAP settings. To the best of the researcher's knowledge, no research has been done on the impact of deferred tax adjustments on EVA within a South African context. As a result, this paper investigates the impact of the deferred tax adjustment on EVA for the Johannesburg Stock Exchange (JSE)-listed food producers.

\section{RESEARCH METHODOLOGY}

The research methodology encompasses the research design used for this study, which is followed by a discussion of the target population, sampling method, data collection, data analysis and formulation of the hypotheses. The section ends with a brief discussion on how validity was achieved.

\subsection{Research design}

\subsubsection{Quantitative research study}

A close examination into sample companies unadjusted $E V A$ and adjusted $E V A$ values was required, to solve the research problem. This study calculated the unadjusted EVA and adjusted EVA val- ues from company's annual financial statements (AFS). This showed that the entire data collection and data analysis constitute numerical data, and is therefore a quantitative research study.

\subsubsection{Time horizon}

This study calculated and analyzed independent variables (deferred tax expenses \& deferred tax assets/deferred tax liabilities) and dependent variables (unadjusted $E V A$ and adjusted $E V A$ ) for each year, over a seven-year period starting from 2004 to 2010. For this reason, this study is longitudinal in nature.

\subsubsection{Type of investigation}

The primary aim of this research was to determine if the deferred tax adjustment causes a major change in the EVA measure. A causal study was selected to establish any causal relationships between variables. In other words, the causal study was undertaken to determine if variable $\mathrm{X}$ causes variable $\mathrm{Y}$. Hence, the statistical analysis produced correlational statistics to measure the impact of the independent variable on the dependent variable.

\subsubsection{Research strategy}

An experimental design was chosen to study causal links between variables and to furthermore examine whether a change in one independent variable produces a change in the dependent variable.

The experimental design focused on the pre-measurement and post-measurement of the dependent variable. In particular, the pre-measurement of the dependent variable constituted the EVA measure without the deferred tax adjustment, whereas the post-measurement of the dependent variable constituted the EVA measure with the implementation of the deferred tax adjustment. To elaborate, the experimental design had a control variable and an experimental variable. The control variable (unadjusted EVA) was the EVA without deferred tax adjustment, which is the dependent variable without any intervention. The experimental variable (adjusted $E V A$ ) was the $E V A$ measure with the implementation of the deferred tax adjustment, which is the dependent variable with planned intervention. 


\subsection{Target population}

Drury (2011) states that listed companies who trade shares on the stock market are more likely to adopt EVA. Therefore, the target population constituted 50 industrial sectors from the JSE.

\subsection{Sampling method}

This study used a purposive sampling method. The aim of this sampling method was to choose an industrial sector from the JSE that adopted EVA. A study by Alzawahreh and Khasawneh (2011) presented an empirical finding which showed that companies in the food producer sector used a defender strategy. Furthermore, Lovata and Costigan (2002) stated that companies, which used a defender strategy, adopted EVA. For this reason, the food producers sector was selected for the purposes of this study.

The sample population for this study constituted a total of 14 JSE-listed companies from the food producers sector. However, due to missing information on the McGregors BFA database, the final sample constituted 9 JSE-listed food producing companies.

\subsection{Data collection}

The sample companies AFS together with supporting financial information was downloaded from the McGregor's BFA database. Three types of data sets were downloaded from McGregors BFA database include the statement of comprehensive income, the statement of financial position and the weighted average cost of capital (WACC) calculations. In addition, the last data set included taxation rates that was obtained from the South African Revenue Services (SARS) website. The four data sets constituted the secondary data for this study. The company AFS, WACC calculations and taxation rates are viewed as secondary data, as it was prepared by a third party.

\subsection{Data analysis}

The author used the abovementioned data sets to conduct the data analysis. The data analysis for this study was done on an excel spreadsheet and is referred to as the 'EVA and deferred tax analysis'. The EVA and deferred tax analysis constitute cal- culations of the unadjusted $E V A$, the deferred tax adjustment and the adjusted EVA.

The statement of comprehensive income was used to calculate the unadjusted NOPAT, and was used to locate values of deferred tax expenses to calculate the adjusted NOPAT. To note, the taxation rates was taken into account in the NOPAT calculations. The statement of financial position was used to calculate the unadjusted TCE, and was used to locate the values of the deferred tax liabilities to calculate the adjusted TCE.

The following formulae, as specified by Bennett Stewart and Joel Stern,were used for the EVA and deferred tax analysis:

\section{Deferred tax adjustment as specified by Stern Stewart:}

- Increases in deferred tax expenses - add back to the unadjusted NOPAT

- Decreases in deferred tax expenses - subtract from the unadjusted NOPAT

- Deferred tax liability - add back to the unadjusted TCE

- Deferred tax asset - subtract from the unadjusted TCE

\section{EVA formulae as specified by Stern Stewart:}

- $\quad$ Unadjusted $E V A=$ Unadjusted NOPAT (Unadjusted $T C E \times W A C C \%$ )

- $\quad$ Adjusted EVA = Adjusted NOPAT (Adjusted $T C E \times W A C C \%$ )

With reference to the above formulae, the unadjusted EVA represents EVA without the implementation of the deferred tax adjustment, this means that the values of deferred tax are included in the unadjusted EVA.

The above formulae were used to remove the deferred taxes from EVA. This required removing the components of deferred taxes (deferred tax expenses and deferred tax liabilities) from the components of EVA (NOPAT and TCE). To elaborate, the deferred tax expenses were removed from the unadjusted NOPAT to arrive at the adjusted NOPAT. In addition, the deferred tax liabilities were removed from the unadjusted TCE to arrive at the adjusted TCE. 
The implementation of the deferred tax adjustment results in the removal of deferred taxes from the unadjusted EVA to arrive to the adjusted EVA. The adjusted EVA represents a more accurate $E V A$, as the distorting impact of deferred taxes are removed. The EVA and deferred tax analysis was computed for all nine food producers (see to Appendix I for the EVA and deferred tax analysis of a sample company).

The EVA and deferred tax analysis served as an input to compute descriptive statistics and inferential statistics These statistics are interpreted to either accept/reject the hypothesis and, hence, answer the research problem.

\subsection{Research hypotheses}

The study formulated the following research hypotheses:

- the null hypothesis for this study was:

${ }^{*} \mathrm{H} 0=$ The deferred tax adjustment has no significant impact on the EVA measure;

- the alternate hypothesis for this study was:

${ }^{*} \mathrm{H} 1=$ The deferred tax adjustment has a significant impact on the EVA measure.

The hypotheses were developed to examine if there is a relationship between the independent variable (deferred tax) and the dependent variable (EVA). Consequently, a regression analysis was se- lected for this study. In addition, the regression analysis provided an indicator of the statistical significance of relationships. The statistical significance output from the regression analysis was used to determine the rejection/acceptance of the alternate hypothesis.

\subsection{Validity}

This study was conducted under laboratory experimental conditions. This means that all nuisance variables had been controlled (Zikmund, Babin, Carr, \& Griffin, 2013). The nuisance variables included all other accounting adjustments and nonaccounting adjustments. The unadjusted EVA and adjusted EVA models measured what they intended to measure, as all other variables that would otherwise affect EVA were controlled. The use of the EVA formulae ensured construct validity. In addition, the data on the spreadsheet (EVA and deferred tax analysis) were verified on several occasions with the data downloaded from the McGregors database to ensure face validity.

\section{EMPIRICAL RESULTS}

\subsection{Descriptive statistics}

Figure 1 shows the mean value of deferred tax expenses for each company over the sample period (2004-2010). An increase in deferred tax expenses is depicted by a horizontal bar to the right, indicating that the company owes taxes to the receiver of

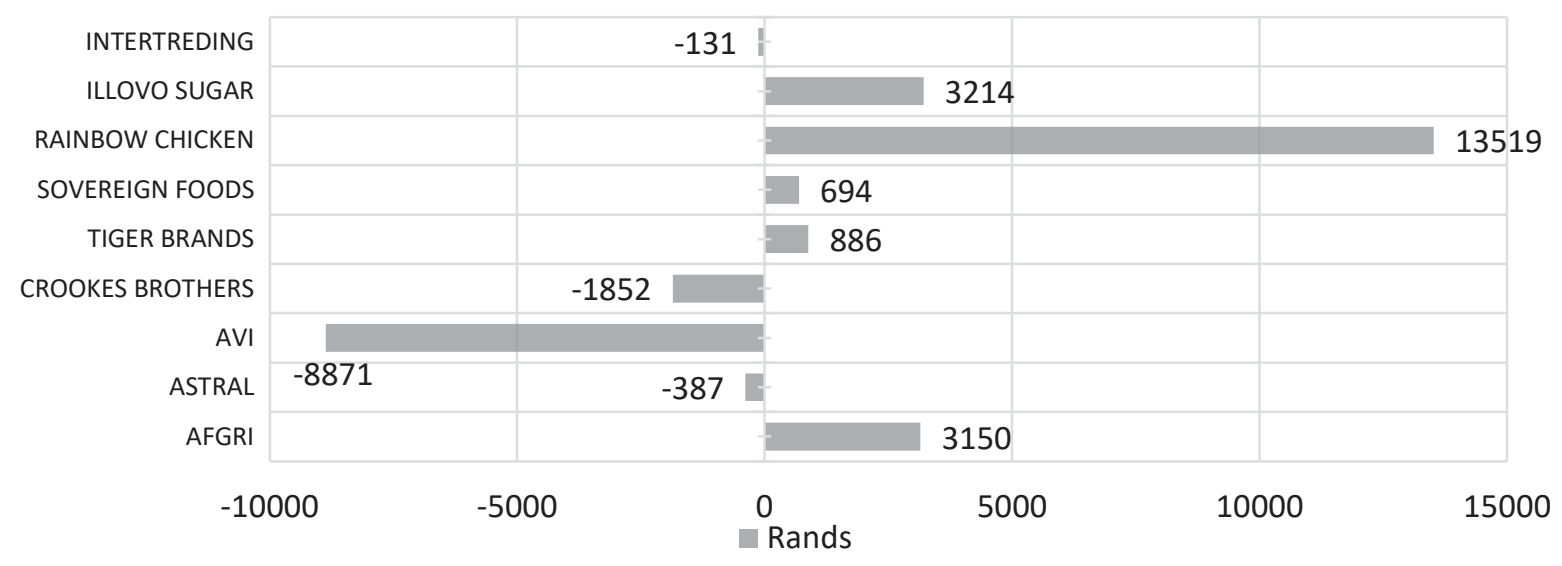

Figure 1. Increases and decreases in deferred tax expenses (Rand values in 000's) 


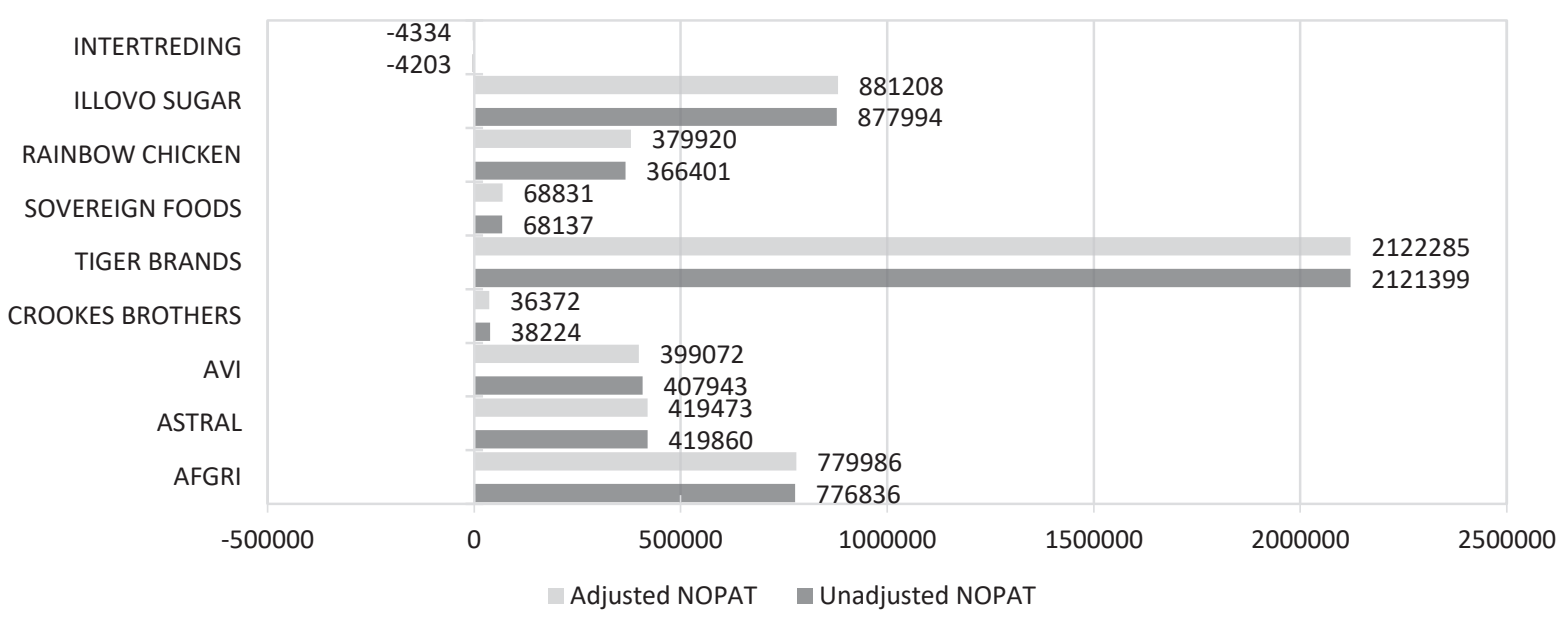

Figure 2. The unadjusted NOPAT and the adjusted NOPAT (Rand values in 000's)

revenue. The decrease in deferred tax expenses is depicted by the horizontal bar to the left, indicating that the company is due for a tax refund from the receiver of revenue. Figure 1 shows that five companies experienced an increase in deferred tax expenses, whilst the other four companies experienced a decrease in deferred tax expenses.

Figure 2 shows the unadjusted NOPAT (before the deferred tax adjustment) and the adjusted NOPAT (after the deferred tax adjustment) for all nine sample companies. The implementation of the deferred tax adjustment to NOPAT entails the removal of deferred tax expenses from the unadjusted NOPAT to arrive at the adjusted NOPAT.

Therefore, the findings from Figure 1 and Figure 2 are interpreted together. For example, Afgri Limited reported an increase in deferred taxes (taxes owing) of R3 150 000. Also, Afgri Limited had a unadjusted NOPAT (with deferred taxes) of R776 836000 . When deferred tax expenses are removed, the adjusted NOPAT is R779 986000 . The increase in deferred tax expenses (taxes owing) resulted in the unadjusted NOPAT being lower than the adjusted NOPAT. To elaborate, an increase in deferred tax expenses understated the value of the NOPAT. The NOPAT value was understated for five food producers.

The findings for the current study is compared with the literature findings from previous studies. Phillips, Pincus, and Rego (2002) examined the usefulness of deferred tax expenses in detecting the management of NOPAT. The results of the study suggested that an increase in deferred tax expenses resulted in an understated NOPAT value. The previous literature findings concur with the current empirical findings.

In contrast, Figure 1 and Figure 2 also illustrate how a decrease in deferred tax expenses (tax refund) affects NOPAT. AVI Limited reported a decrease in deferred tax expenses of R8 871000 . AVI Limited had a unadjusted NOPAT of R407 943000. When deferred tax expenses are removed, the value of the adjusted NOPAT is R399 072000 . A comparison of the unadjusted and adjusted NOPAT shows that the unadjusted NOPAT is higher than the adjusted NOPAT. This implies that a decrease in deferred tax expense overstated the value of NOPAT. The NOPAT value was overstated for four food producers.

The current empirical findings can be compared with the literature findings. The study by Noor et al. (2005) investigated the reason for the widening gap between the unadjusted NOPAT and the adjusted NOPAT. The study showed that the widening gap was due to the management of NOPAT through the use of deferred tax expenses. Furthermore, the previous literature findings revealed that a decrease in deferred tax expenses resulted in an overstated NOPAT value. Therefore, the literature findings by Noor et al. are in agreement with the current empirical findings. 


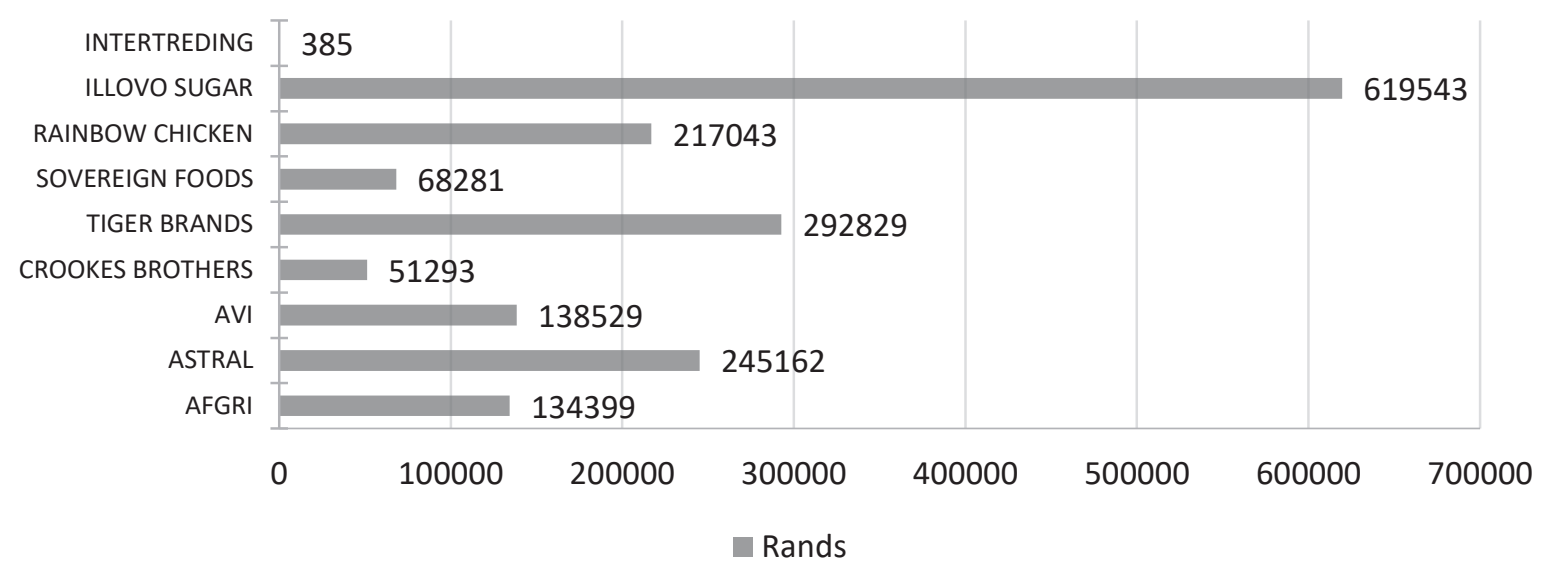

Figure 3. Deferred tax liabilities (Rand values in 000's)

Figure 3 shows the mean value of deferred tax liabilities for each of the nine companies in the food producer sector. With reference to Figure 3, all nine companies in the food producer sector reported deferred tax liabilities. To add, each company reported a deferred tax liability for each of the seven years starting from the period 2004-2010. No deferred tax assets were reported during the sample period.

Figure 4 shows the unadjusted TCE (before the deferred tax adjustment) and the adjusted TCE (after the deferred tax adjustment) for all nine sample companies. To elaborate, the implementation of the deferred tax adjustment to TCE entails the removal of deferred tax liabilities from the unadjusted TCE to arrive at the adjusted TCE.
The empirical findings for Figure 3 and Figure 4 are interpreted together, because the value of the deferred tax liability impacts the value of TCE. For example, Afgri Limited reported an unadjusted TCE of R4 132012 000. The removal of deferred tax liabilities resulted in an adjusted TCE of R4 266412 000. A comparison of the unadjusted TCE with the adjusted TCE showed that unadjusted TCE is lower than the adjusted TCE. This result confirms that the value of the deferred tax liability understated TCE. The TCE value was understated for all nine food producers.

A study by Gee and Mano (2006) showed that managers were using deferred tax assets to manage the value of TCE. The results from the study indicated that companies were recognising deferred tax assets to produce an overstated TCE. The previous

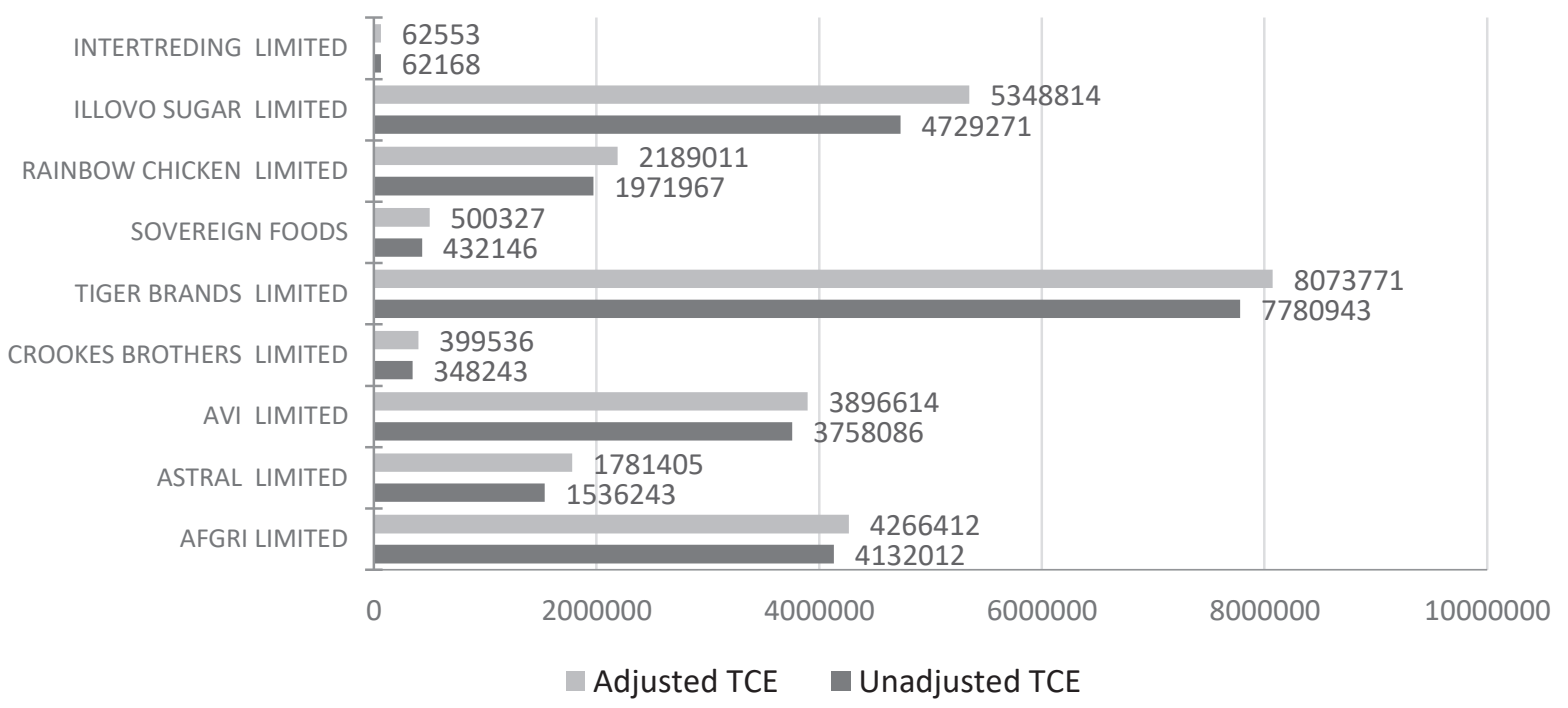

Figure 4. The unadjusted TCE and the adjusted TCE (Rand values in 000's) 
study also mentioned that if companies reported a deferred tax liability, an understated TCE would be produced. Therefore, the previous literature findings agree with the current empirical findings.

To conclude, the descriptive statistics analysed the relationships between deferred taxes and EVA. This was done by examining the relationships between the components of EVA (NOPAT and TCE) with the components of deferred tax (deferred tax expense and deferred tax liability). These descriptive results showed that deferred tax expenses distort NOPAT and that deferred tax liabilities distort $T C E$. Hence, descriptive findings revealed that deferred taxes distort $E V A$.

\subsection{Inferential statistics}

The inferential results constitute regression statistics, the ANOVA test for overall significance and the coefficient test for individual significance for both the unadjusted EVA and adjusted EVA.

Table 1. Multiple regression model of the unadjusted EVA

\begin{tabular}{|c|c|c|c|c|}
\hline \multicolumn{5}{|c|}{ Model summary } \\
\hline Model & $\mathbf{R}$ & R square & $\begin{array}{l}\text { Adjusted } \\
\text { R square }\end{array}$ & $\begin{array}{c}\text { Std. error } \\
\text { of the estimate }\end{array}$ \\
\hline 1 & $1.000^{\mathrm{a}}$ & 1.000 & 1.000 & 0.385 \\
\hline
\end{tabular}

Note: a. Predictors: (constant), unadjusted cost of capital, unadjusted NOPAT, unadjusted TCE.
With reference to Table 1, the unadjusted EVA regression model yielded a perfect positive correlation of +1 . This implies that the independent variables accurately predict the value of the (unadjusted EVA) dependent variable.

With reference to Table 2, the ANOVA (f-tests) evaluated the overall significance of the independent variables on the dependent variable. The findings revealed that all independent variables, (unadjusted NOPAT, unadjusted TCE and the unadjusted cost of capital) had an overall significance (p-value $<0.05$ ) in predicting the value of the unadjusted $E V A$.

Table 3 shows the coefficient test for individual significance. The results revealed that the unadjusted NOPAT and the unadjusted cost of capital were the most significant variables in predicting the value of the unadjusted EVA. However, the unadjusted TCE lacked statistical significance (pvalue $>0.05$ ) in predicting the value of the unadjusted EVA. The reason for the lack of significance on the unadjusted TCE variable is inherent in the formulae used to calculate the value of EVA. The TCE forms an important component in the EVA formula. However, the TCE cannot determine the value of the EVA in isolation. The lack of completeness in this component led to the lack of significance as the multiplication of TCE by the WACC\% makes the component of EVA complete and meaningful. In addition, the following unadjusted $E V A$

Table 2. ANOVA test for overall significance

\begin{tabular}{|c|c|c|c|c|c|c|}
\hline \multicolumn{7}{|c|}{ ANOVA $^{\mathrm{a}}$} \\
\hline & Model & Sum of squares & df & Mean square & $\mathbf{F}$ & Sig. \\
\hline \multirow{3}{*}{1} & Regression & 12772919748781.700 & 3 & 4257639916260.560 & 28757108110560.200 & $0.000^{\mathrm{b}}$ \\
\hline & Residual & 8.735 & 59 & 0.148 & & \\
\hline & Total & 12772919748790.400 & 62 & & & \\
\hline
\end{tabular}

Notes: a. Dependent variable: unadjusted EVA (method 1). b. Predictors: (constant), unadjusted cost of capital, unadjusted NOPAT, unadjusted TCE.

Table 3. Coefficient test for individual significance

\begin{tabular}{|c|c|c|c|c|c|c|}
\hline \multicolumn{7}{|c|}{ Coefficients $^{\mathrm{a}}$} \\
\hline & \multirow{2}{*}{ Model } & \multicolumn{2}{|c|}{ Unstandardized coefficients } & \multirow{2}{*}{$\frac{\text { Standardized coefficients }}{\text { Beta }}$} & \multirow{2}{*}{$\mathbf{t}$} & \multirow{2}{*}{ Sig. } \\
\hline & & B & Std. Error & & & \\
\hline \multirow{4}{*}{1} & (Constant) & -0.084 & 0.071 & & -1.179 & 0.243 \\
\hline & Unadjusted NOPAT & 1.000 & 0.000 & 1.557 & 7927466.069 & 0.000 \\
\hline & Unadjusted TCE & $5.160 \mathrm{E}-08$ & 0.000 & 0.000 & 0.608 & 0.545 \\
\hline & Unadjusted Cost of capital & -1.000 & 0.000 & -0.782 & 1509010.857 & 0.000 \\
\hline
\end{tabular}

Note: a. Dependent variable: unadjusted EVA (method 1). 
Table 4. Multiple regression model of the adjusted EVA

\begin{tabular}{c|c|c|c|c}
\hline & & \multicolumn{3}{c}{ Model summary } \\
\hline Model & $\mathbf{R}$ & R square & Adjusted R square & Std. Error of the estimate \\
\hline 1 & $1.000^{\mathrm{a}}$ & 1.000 & 1.000 & 0.382 \\
\hline
\end{tabular}

Note: a. Predictors: (constant), adjusted cost of capital, deferred tax expenses impacting NOPAT, Deferred tax liabilities impacting TCE, unadjusted NOPAT, adjusted TCE.

Table 5. ANOVA test for overall significance

\begin{tabular}{|c|c|c|c|c|c|c|}
\hline \multicolumn{7}{|c|}{ ANOVA $^{a}$} \\
\hline & Model & Sum of squares & $f$ & Mean square & $\mathbf{F}$ & Sig. \\
\hline \multirow{3}{*}{1} & Regression & 12578959126479.700 & 5 & 2515791825295.940 & 17278537831752.700 & $0.000^{\mathrm{b}}$ \\
\hline & Residual & 8.300 & 57 & 0.146 & & \\
\hline & Total & 12578959126488.000 & 62 & & & \\
\hline
\end{tabular}

Notes: a. Dependent variable: adjusted EVA (method 1). b. Predictors: (constant), adjusted cost of capital, deferred tax expenses impacting NOPAT, deferred tax liabilities impacting TCE, unadjusted NOPAT, adjusted TCE.

regression equation for Food producers was formulated from Table 3.

Unadjusted $E V A=-0.084+$ unadjusted NOPAT + + unadjusted cost of capital.

With reference to the coefficient test for individual significance, the current empirical findings are compared to previous literature findings. Previous empirical evidence by Lynn, Seethamraju, and Seetharaman (2008) showed that the unadjusted NOPAT was statistically significant. The comparison of empirical findings showed that the current empirical findings are in agreement with previous literature findings.

With reference to Table 4, the adjusted EVA regression model yielded a perfect positive correla- tion value of +1 . This implies that the independent variables predict $100 \%$ of the dependent variable (adjusted $E V A$ ).

With reference to Table 5, the ANOVA (f-test) showed that all independent variables had an overall significance on the dependent variable. The findings revealed that all five independent variables had an overall significance (p-value < 0.05 ) on the value of the adjusted $E V A$.

Table 6 shows the coefficient test for individual significance. The results showed that the unadjusted NOPAT, the deferred taxes that impact NOPAT and the adjusted cost of capital variables significantly impacted ( $p$-value $<0.05)$ the value of the adjusted EVA. However, the deferred taxes that impacted TCE and the unadjusted TCE were

Table 6. Coefficient test for individual significance

\begin{tabular}{|c|c|c|c|c|c|c|}
\hline \multicolumn{7}{|c|}{ Coefficients $^{\mathrm{a}}$} \\
\hline & \multirow{2}{*}{ Model } & \multicolumn{2}{|c|}{ Unstandardized coefficients } & \multirow{2}{*}{$\begin{array}{c}\text { Standardized } \\
\text { coefficients } \\
\text { Beta }\end{array}$} & \multirow[t]{2}{*}{$\mathbf{t}$} & \multirow{2}{*}{ Sig. } \\
\hline & & B & Std. Error & & & \\
\hline \multirow{6}{*}{1} & (Constant) & -0.127 & 0.075 & & -1.698 & 0.095 \\
\hline & Unadjusted NOPAT & 1.000 & 0.000 & 1.569 & 7986474.723 & 0.000 \\
\hline & $\begin{array}{l}\text { Deferred tax expenses impacting } \\
\text { NOPAT }\end{array}$ & 1.000 & 0.000 & 0.078 & 716624.832 & 0.000 \\
\hline & Deferred tax liabilities impacting TCE & $-2.384 \mathrm{E}-08$ & 0.000 & 0.000 & -0.076 & 0.940 \\
\hline & Unadjusted TCE & $4.410 \mathrm{E}-08$ & 0.000 & 0.000 & 0.519 & 0.606 \\
\hline & Adjusted Cost of capital & -1.000 & 0.000 & -0.819 & 1573007.896 & 0.000 \\
\hline
\end{tabular}

Note: a. Dependent variable: adjusted EVA (method 1). 
not individually significant (p-value $>0.05$ ) in predicting the value of the dependent variable. In addition, the following adjusted EVA regression equation for food producers was extracted from Table 6.

Adjusted $E V A=-0.127+$ unadjusted NOPAT + + deferred tax expenses impacting NOPAT + tadjusted cost of capital.

With reference to Table 6, the current empirical findings are compared to previous literature findings. A previous study by Noor et al. (2007) found deferred taxes that impacted NOPAT was statistically significant. The empirical results from the current study are in agreement with the previous literature findings.

In addition, Gallemore (2012) found deferred taxes that impacted TCE were statistically significant. The finding by Gallemore contrasts with the current empirical findings, because the study by Gallemore reported a deferred tax asset, whilst the current study reported deferred tax liabilities.

The above comparison shows a variation of empirical results for individual significance of independent variables. The current study shows five independent variables, of which three are statistically significant, whilst the remaining two independent variables are not statistically significant. Although there is a lack of statistical significance amongst some of the independent variables, the study shows a high overall statistical significance for the majority of the independent variables. The variation of empirical findings is also due to the nature of the previous studies that only evaluate specific components of $E V A$, whereas the current study investigated the entire EVA model. To summarize, the current empirical findings are in partial agreement with the previous literature findings.

\section{LIMITATIONS}

The multiple regression models were specifically designed for companies in the food producers sector. Therefore, the results for the current study are specific to companies in the food producers sector. The impact of the deferred tax adjustment could vary amongst other industrial sectors. Consequently, the results of the study can only be generalized for the companies in the food producers sector.

\section{SUGGESTIONS FOR FUTURE RESEARCH}

Sharma and Kumar (2010) state that companies are experiencing difficulties in implementing EVA adjustments. The current research study assists in bridging the knowledge gap by investigating the impact of deferred taxes on EVA. However, more research should be done on other types of EVA adjustments. Also, future research should focus on external factors that could impact the accuracy of EVA.

\section{CONCLUSION AND RECOMMENDATIONS}

The aim of this study was to determine the impact of the deferred tax adjustment on EVA for JSE-listed food producers in South Africa. The descriptive statistics provided two main empirical findings. The first empirical finding that an increase in deferred tax expenses understated NOPAT, whilst a decrease in deferred tax expenses overstated NOPAT. The second empirical finding revealed that deferred tax liabilities understated TCE.

In addition, the regression statistics revealed an overall statistical significance for all deferred tax predictors in relation to EVA. The regression results led to the rejection of the null hypothesis. This research study, therefore, proved the stated hypothesis, that deferred tax has a significant impact on EVA. As a result, the current study concluded that deferred taxes significantly impacted EVA.

The above findings show that deferred taxes distort the value of EVA. Furthermore, the regression statistics show that deferred taxes significantly impact EVA. The implementation of the deferred tax adjust- 
ment will remove the distorting effects of deferred taxes on EVA. A further motivation for the implementation of the deferred tax adjustment relates to the aspect of cash flows. The EVA measure represents actual cash flows, whilst deferred taxes do not represent actual cash flows, thus providing another reason for the implementation of the deferred tax adjustment (removal of deferred taxes from EVA).

The deferred tax adjustment will improve the accuracy of EVA. An accurate EVA measure will benefit managers and shareholders, who use EVA for decision-making purposes. Shareholders will benefit, as they will know with a reasonable degree of accuracy, the amount of wealth the company has created for their investment in shares. In addition, managers that use the EVA measure will be able to make better and well-informed decisions, which, in turn, impact shareholder wealth. Therefore, the study recommends that companies implement the deferred tax adjustment.

To date, there is no empirical evidence measuring the impact of deferred taxes on EVA. This study is the first to provide empirical evidence on the impact of deferred taxes on EVA, which is reflected in the descriptive and inferential statistics of this study. Consequently, this study has established the behavioral pattern of deferred taxes on $E V A$, this behavioral pattern will not change as the deferred tax variable and the $E V A$ variable was calculated using $E V A$ formulae (formulae were developed by the pioneers of $E V A$, Bennett Stewart and Joel Stern). Therefore, the research results from this study remains relevant regardless of the timing concerning the data collection and data analysis.

In addition, the empirical results from this study will serve as historical data to future researchers and practitioners examining deferred taxes and its impact on EVA. Lastly, the data analysis that utilized data from 2004 to 2010 produced regression models that will be useful in predicting future trends for EVA and deferred tax.

\section{REFERENCES}

1. Abbott, M. L., \& McKinney, J. (2013). Understanding and applying research design. United States of America: Wiley. Retrieved from http://site.ebrary.com/lib/durbanut/Doc?id=10657581\&ppg $=62$

2. Alzawahreh, A., \& Khasawneh, S. (2011). Business strategies adopted by Jordanian organizations: The key to a sustained competitive advantage. Interdisciplinary Journal of Contemporary Research in Business, 3(5), 508-524. Retrieved from http://journal-archieves8. webs.com/508-524.pdf

3. Anderson, A. M., Bey, R. P., \& Weaver, S. C. (2005). Economic value added adjustments: much to do about nothing. Retrieved from www.lehigh.edu/ incbeug/Attachments/Anderson\%20EVA\%20 4-7-05.pdf

4. Aubert, F. (2009). The relative informative ness of GAAP and pro forma earnings announcements in France. Retrieved from http:// papers.ssrn.com/sol3/papers.

cfm?abstract_id=1414423

5. Bhattacharya, N., Black, E. L., Christensen, T. E., \& Larson, C. R. (2003). Assessing the relative informative ness and permanence of pro forma earnings and GAAP operating earnings. Journal of Accounting and Economics, 36, 285319. http://dx.doi.org/10.1016/j. jacceco.2003.06.001

6. Black, D. E., \& Christensen, T. E. (2009). U.S managers use of pro forma adjustments to meet strategic earnings targets. Journal of Business Finance and Accounting, 36(3,4), 297-326. Retrieved from http://papers.ssrn.com/sol3/papers.cfm?abstract_id=1400373

7. Bryan, S. H., Lilien, S., \& Martin, D. R. (2010). The financial statement effects of capitalizing operating leases. The CPA Journal, 80(8), 36-41. Retrieved from http://dutlib.dut.ac.za:2057/ docview/749930439
8. Burksaitiene, D. (2009). Measurement of value creation: Economic Value Added and Net Present Value. Economics \& Management, 709-714. Retrieved from http://web.ebscohost.com/ ehost/pdfviewer/pdfviewer? hid $=9 \&$ sid $=$ b266e $81 \mathrm{c}-0 \mathrm{c} 31-4724-$ bcd4-8a1ad31a26e2\%40session mgr11 2\&vid=6

9. Callimaci, A., \& Landry, S. (2004). Market valuation of research and development spending under Canadian GAAP. Canadian Accounting Perspectives, 3(1), 33-53. http:// dx.doi.org/10.1506/V5LY-4CNE3J0Q-00HN

10. Cazavan-Jeny, A., \& Jeanjean, T. (2006). The negative impact of R\&D capitalization: A value relevance approach. European Accounting Review, 15(1), 37-61. http://dx.doi. org/10.1080/09638180500510384

11. Chang, C., Herbohn, K., \& Tutticci, I. (2009). Market's percep- 
tion of deferred tax accruals. Accounting and Finance, 645-673. http://dx.doi.org/10.1111/j.1467629X.2009.00307.x

12. Collier, P. M. (2012). Accounting for managers: Interpreting accounting for decision-making. United Kingdom: John Wiley and Sons Limited.

13. Damodaran, A. (2007). ROC, ROIC and ROE: Measurement and implications. Retrieved from http://papers.ssrn.com/sol3/papers.cfm?abstract_id $=1105499$

14. Damodaran, A. (2009). Leases, debt and value. Retrieved from http://papers.ssrn.com/sol3/papers.cfm?abstract_id $=1390280$

15. Drury, C. (2011). Cost and management accounting: An introduction. England: SouthWestern/Cengage Learning.

16. Eames, M. J., \& Sepe, J. (2005). The valuation of special items. Journal of Applied Business Research, 21(3), 61-70. Retrieved from: http://journals.cluteonline. com/index.php/JABR/article/ view/1469

17. Gallermore, J. (2012). Deferred tax assets and bank regulatory capital. Retrieved from http://ssrn.com/ abstract $=2025031$

18. Gee, M. A., \& Mano, T. (2006). Accounting for deferred tax in Japanese banks and the consequences for their international operations. Abacus, 42(1), 1-21. http://dx.doi.org/10.1111/j.14676281.2006.00190.x

19. Herbohn, K., Tutticci, I., \& Khor, P. S. (2010). Changes in unrecognized deferred tax accruals from carry-forward losses: Earnings management or signaling. Journal of Business Finance and Accounting, 37(7), 763-791. http://dx.doi.org/10.1111/j.14685957.2010.02207.x
20. Larrabee, D. T., \& Voss, J. A. (2012). Valuation techniques: discounted cash flow, earnings quality, measures of value added and real options. United States of America: Wiley. Retrieved from http:// site.ebrary.com/lib/durbanut/ Doc $? \mathrm{id}=10613139$ \&ppg $=54$

21. Latha, C. (2009). Measuring value enhancement through Economic Value Added: Evidence from literature. IUP Journal of Applied Finance, 15(9), 46-62. Retrieved from http://web.ebscohost. com/ehost/ pdfviewer/pdfviewer?hid=110\&sid=b266e81c0c31-4724-bcd4-8a1ad 31a26 e2\% 40sessionmgr 112\&vid $=6$

22. Lovata, L. M., \& Costigan, M. L. (2002). Empirical analysis of adopters of economic value added. Management Accounting Research, 13(2), 215-228. http://dx.doi. org/10.1006/mare.2002.0181

23. Lynn, S., Seethamraju, C., \& Seetharaman, A. (2008). Incremental value relevance of unrecognized deferred taxes: Evidence from the United Kingdom. American Accounting Association, 30(2), 107-130. Retrieved from http://search. proquest.com/docview/211073155 /1373C81ECDD5CD249 44/4?accountid $=10612$

24. Marques, A. (2010). Disclosure strategies among S \& P 500 firms: Evidence on the disclosure of nonGAAP financial measures and financial statements in earnings press releases. British Accounting Review, 42, 119-131. http://dx.doi. org/10.1016/j.bar.2010.02.004

25. Nichols, N. B., Gray, S. J., \& Street, D. L. (2005). Pro forma adjustments to GAAP earnings: bias, materiality and SEC action. Research in Accounting Regulation, 18, 29-52. http://dx.doi.org/10.1016/ S1052-0457(05)18002-3
26. Noor, R. M., Mastuki, N., \& Aziz, Z. (2007). Earnings management and deferred tax. Malaysian Accounting Review, 6(1), 1-17. Retrieved from http://eprints.ptar. uitm.edu.my/4198/1/J_MARv6n10701.pdf

27. Phillips, J., Pincus, M., \& Rego, S. O. (2002). Earnings management: New evidence based on deferred tax expense. Retrieved from http://papers.ssrn.com/sol3/papers.cfm?abstract_id=276997

28. Quinlan, C. (2011). Business research methods. United Kingdom: Cengage Learning.

29. Ray, R. (2001). Economic Value Added: Theory, evidence, a missing link. Review of Business, 22 (1/2), 66-70. Retrieved from http://search.proquest.com

30. Sharma, A. K. \& Kumar, S. (2010). Economic Value Added (EVA) Literature review and relevant issues. International Journal of Economics and Finance, 2(2), 200220. http://dx.doi.org/10.5539/ijef. v2n2p200

31. Stewart, B. (1991). The quest for value: a guide for senior managers. New York: Harper Business.

32. Stewart, B. (2013). Best practice EVA: The ultimate solution for value-based corporates. United States of America: Wiley. Retrieved from http://site.ebrary.com/lib/durbanut $/$ Doc? $\mathrm{id}=10660609 \& p p g=98$

33. Young, D. (1997). Economic value added: A primer for European managers. European Management Journal, 15(4), 335-343. http://dx.doi.org/10.1016/S02632373(97)00014-5

34. Zikmund, W. G., Babin, B. J., Carr, J. C., \& Griffin, M. (2013). Business research methods. United States of America: Cengage Learning. 


\section{APPENDIX}

Table A1. EVA and deferred tax analysis (sample company: AFGRI Limited)

\begin{tabular}{|c|c|c|c|c|c|c|c|}
\hline \multirow{2}{*}{ AFGRI LIMITED } & \multicolumn{7}{|c|}{ Year } \\
\hline & 2010 & 2009 & 2008 & 2007 & 2006 & 2005 & 2004 \\
\hline NOPAT & 898220 & 1335368 & 1188561 & 738497 & 572244 & 286499 & 418462 \\
\hline Less: cost of capital & 824465 & 845467 & 595647 & 201634 & 406891 & 185231 & 279157 \\
\hline EVA (unadjusted) & 73755 & 489902 & 592914 & 536863 & 165353 & 101268 & 139305 \\
\hline \multicolumn{8}{|c|}{ Calculation of NOPAT (unadjusted) } \\
\hline Profit after tax and interest & 272754 & 413561 & 356617 & 342997 & 202272 & 182603 & 272248 \\
\hline Plus: interest and finance charges & 488645 & 720162 & 644918 & 306589 & 286800 & 79920 & 112472 \\
\hline Add: tax benefit on interest expense & 136821 & 201645 & 187026 & 88911 & 83172 & 23976 & 33742 \\
\hline NOPAT & 898220 & 1335368 & 1188561 & 738497 & 572244 & 286499 & 418462 \\
\hline \multicolumn{8}{|c|}{ Calculation of TCE (unadjusted) } \\
\hline Total assets & 9824950 & 9174033 & 7119789 & 3913650 & 3732439 & 2832476 & 3477077 \\
\hline $\begin{array}{l}\text { Less: non-interest bearing current } \\
\text { liabilities (NIBCL) }\end{array}$ & 1797057 & 2015127 & 1680088 & 1445672 & 1749539 & 1032373 & 1430471 \\
\hline Trade creditors & 1475369 & 1745754 & 1188458 & 764816 & 1004548 & 597378 & 795134 \\
\hline Short-term non-interest bearing & 321688 & 269373 & 491630 & 680856 & 744991 & 434995 & 635337 \\
\hline TCE (unadjusted) & 8027893 & 7158906 & 5439701 & 2467978 & 1982900 & 1800103 & 2046606 \\
\hline \multicolumn{8}{|c|}{ Cost of capital calculation } \\
\hline TCE (unadjusted) & 8027893 & 7158906 & 5439701 & 2467978 & 1982900 & 1800103 & 2046606 \\
\hline x Weighted average cost of capital & 0.1027 & 0.1181 & 0.1095 & 0.0817 & 0.2052 & 0.1029 & 0.1364 \\
\hline Cost of capital & 824465 & 845467 & 595647 & 201634 & 406891 & 185231 & 279157 \\
\hline \multicolumn{8}{|c|}{ Calculation of tax shield on interest expense } \\
\hline Interest expense & 488645 & 720162 & 644918 & 306589 & 286800 & 79920 & 112472 \\
\hline $\mathrm{x}$ tax rate & 0.28 & 0.28 & 0.29 & 0.29 & 0.29 & 0.30 & 0.30 \\
\hline Tax benefit on interest expense & 136821 & 201645 & 187026 & 88911 & 83172 & 23976 & 33742 \\
\hline \multicolumn{8}{|c|}{ Calculation of increase/decrease of deferred tax for the year } \\
\hline Deferred tax for previous year & 5116 & 1690 & 23705 & -15155 & -19039 & 8212 & 555 \\
\hline $\begin{array}{l}\text { Subtract: deferred tax for the current } \\
\text { year }\end{array}$ & 22606 & 5116 & 1690 & 23705 & -15155 & -19039 & 8212 \\
\hline $\begin{array}{l}\text { Increase/decrease in deferred tax as } \\
\text { per Income Statement }\end{array}$ & -17490 & -3426 & 22015 & -38860 & -3884 & 27251 & -7657 \\
\hline \multicolumn{8}{|c|}{ Calculation of NOPAT (adjusted) } \\
\hline NOPAT (unadjusted) & 898220 & 1335368 & 1188561 & 738497 & 572244 & 286499 & 418462 \\
\hline $\begin{array}{l}\text { add or less increase/decrease in } \\
\text { deferred tax for the year }\end{array}$ & 17490 & 3426 & 22015 & 38860 & 3884 & 27251 & 7657 \\
\hline NOPAT (adjusted) & 915710 & 1338794 & 1166546 & 777357 & 576128 & 259248 & 426119 \\
\hline \multicolumn{8}{|c|}{ Calculation of TCE (adjusted) } \\
\hline TCE (unadjusted) & 8027893 & 7158906 & 5439701 & 2467978 & 1982900 & 1800103 & 2046606 \\
\hline $\begin{array}{l}\text { Add deferred tax liability and less } \\
\text { deferred tax asset }(\mathrm{B} / \mathrm{S})\end{array}$ & 173836 & 200836 & 192492 & 178129 & 99548 & 40258 & 55696 \\
\hline TCE (adjusted) & 8201729 & 7359742 & 5632193 & 2646107 & 2082448 & 1840361 & 2102302 \\
\hline \multicolumn{8}{|c|}{ Calculation of cost of capital for adjusted EVA measure } \\
\hline TCE (adjusted) & 8201729 & 7359742 & 5632193 & 2646107 & 2082448 & 1840361 & 2102302 \\
\hline x Weighted average cost of capital & 0.1027 & 0.1181 & 0.1095 & 0.0817 & 0.2052 & 0.1029 & 0.1364 \\
\hline Cost of capital & 842318 & 869186 & 616725 & 216187 & 427318 & 189373 & 286754 \\
\hline \multicolumn{8}{|c|}{ Calculation of adjusted EVA measure } \\
\hline NOPAT (adjusted) & 915710 & 1338794 & 1166546 & 777357 & 576128 & 259248 & 426119 \\
\hline Less: cost of capital & 842318 & 869186 & 616725 & 216187 & 427318 & 189373 & 286754 \\
\hline EVA (adjusted) & 73392 & 469609 & 549821 & 561170 & 148810 & 69875 & 139365 \\
\hline
\end{tabular}


Table A1 (cont.). EVA and deferred tax analysis (sample company: AFGRI Limited)

\begin{tabular}{|c|c|c|c|c|c|c|c|}
\hline \multirow{2}{*}{ AFGRI LIMITED } & \multicolumn{7}{|c|}{ Year } \\
\hline & 2010 & 2009 & 2008 & 2007 & 2006 & 2005 & 2004 \\
\hline NOPAT (unadjusted) & 898220 & 1335368 & 1188561 & 738497 & 572244 & 286499 & 418462 \\
\hline NOPAT (adjusted) & 915710 & 1338794 & 1166546 & 777357 & 576128 & 259248 & 426119 \\
\hline $\begin{array}{l}\text { Deferred tax expenses impacting } \\
\text { NOPAT }\end{array}$ & 17490 & 3426 & 22015 & 38860 & 3884 & 27251 & 7657 \\
\hline Deferred tax liability impacting TCE & 173836 & 200836 & 192492 & 178129 & 99548 & 40258 & 55696 \\
\hline TCE (unadjusted) & 8027893 & 7158906 & 5439701 & 2467978 & 1982900 & 1800103 & 2046606 \\
\hline TCE capital (adjusted) & 8201729 & 7359742 & 5632193 & 2646107 & 2082448 & 1840361 & 2102302 \\
\hline Cost of capital (unadjusted) & 824465 & 845467 & 595647 & 201634 & 406891 & 185231 & 279157 \\
\hline Cost of capital (adjusted) & 842318 & 869186 & 616725 & 216187 & 427318 & 189373 & 286754 \\
\hline EVA (unadjusted) (method 1) & 73755 & 489902 & 592914 & 536863 & 165353 & 101268 & 139305 \\
\hline EVA (adjusted) (method 1) & 73392 & 469609 & 549821 & 561170 & 148810 & 69875 & 139365 \\
\hline EVA (unadjusted) (method 2) & 73755 & 489902 & 592914 & 536863 & 165353 & 101268 & 139305 \\
\hline EVA (adjusted) (method 2) & 73392 & 469609 & 549821 & 561170 & 148810 & 69875 & 139365 \\
\hline Return on capital & 0.1119 & 0.1865 & 0.2185 & 0.2992 & 0.2886 & 0.1592 & 0.2045 \\
\hline Minus the cost of capital & 0.1027 & 0.1181 & 0.1095 & 0.0817 & 0.2052 & 0.1029 & 0.1364 \\
\hline Return spread & 0.0092 & 0.0684 & 0.1090 & 0.2175 & 0.0834 & 0.0563 & 0.0681 \\
\hline $\begin{array}{l}\text { Return spread percentage (EVA } \\
\text { unadjusted) }\end{array}$ & 0.92 & 6.84 & 10.90 & 21.75 & 8.34 & 5.63 & 6.81 \\
\hline Return on capital & 0.1116 & 0.1819 & 0.2071 & 0.2938 & 0.2767 & 0.1409 & 0.2027 \\
\hline Minus the cost of capital & 0.1027 & 0.1181 & 0.1095 & 0.0817 & 0.2052 & 0.1029 & 0.1364 \\
\hline Return spread & 0.0089 & 0.0638 & 0.0976 & 0.2121 & 0.0715 & 0.0380 & 0.0663 \\
\hline $\begin{array}{l}\text { Return spread percentage (EVA } \\
\text { adjusted) }\end{array}$ & 0.89 & 6.38 & 9.76 & 21.21 & 7.15 & 3.80 & 6.63 \\
\hline
\end{tabular}

